\title{
POLITICAL STATEMENTS IN THE SOCIAL NETWORKS AND THEIR LINGUISTIC EXAMINATION
}

\author{
Nargisa Solieva
}

Ministry of Justice of The Republic Of Uzbekistan In The Presence Of $\mathbf{H}$. Sulaymonova Republican Center Of Forensic Examination Forensic Examination Of Documents Laboratory Manager, Uzbekistan

\section{ABSTRACT}

The paper deals with the political texts in social media and their linguistic expertise, the existing problems in this field and the current solutions, which have been and should be proposed.

\section{KEYWORDS: - Political text, linguistic expertise, social media, linguistics, legislation, authorship,} responsibility.

\section{INTRODUCTION}

The prestige and place of language as an integral and essential part of society are incomparable. Valuable work is underway in the developed countries on the practical importance of language and its effective use. With the intensification of international relations, one of the urgent tasks is to bring research in this field to a new level in Uzbekistan. In particular, solving social, economic, scientific, educational and political problems by developing several fields, such as psycholinguistics, neurolinguistics and linguistic expertise, which are relatively new to our linguistics, becomes more important than ever.

Today, the role and place of social media in the exchange of information is unexceptionally high. One of the important tasks is to implement correct and fair policies in public administration, in order to take into account the opinion of the people on social networks as a democratic state. It is no secret that today there are difficulties related to different interpretations of political texts for various objective and subjective reasons. It is important to understand this issue scientifically and thereby conduct research to solve the obstacles of officials and people in this regard.

Initially, it should be noted that a political statement as a complex phenomenon has a number of features. Firstly, a political statement is a type of text that is used by the politicians. Secondly, this type of statement deals with specific topics, in particular political issues. According to scholars, a political statement is a text created by people 
CURRENT RESEARCH JOURNAL OF PHILOLOGICAL SCIENCES 2(12):

227-231, December 2021

DOI: https://doi.org/10.37547/philological-crjps-02-12-43

ISSN 2767-3758

(C2021 Master Journals

Crossref do

gil Google

Accepted26 ${ }^{\text {th }}$ December, 2021 \& Published $31^{\text {th }}$ December, 2021

engaged in political activities [2]. It should be noted that there are narrow and broad approaches to the study of political statement. That is, according to the narrow approach, only statement created by direct politicians are political, according to the broad approach, political statement include any texts on a political topic [5. 196].

The peculiarity of a political statement is also characterized by the fact that it is aimed at influencing a group of people. One of the most important characteristics of a political statement is to influence, as its function is to achieve a certain result by influencing the recipient of information. According to another definition, a political statement is a text dealing with topical political issues and intended for a mass audience [1. 15]. Researchers of political speech note that a significant feature of this type of speech is that it reflects the activities of a political association, such as a party, other public organizations, public administration bodies and political activists.

These activities are aimed at influencing the political situation by promoting certain ideas. A political statement focuses directly or indirectly on "questions of the distribution and use of political power" [4. [4. 89]. A political statement performs a number of functions that are inextricably linked to its main purpose - interaction. The following functions of a political statement can be distinguished: first, information is essential because information is the purpose of any political statement. This function is designed to convey sufficient information about the event or policy described itself.

In order to successfully achieve the main purpose of a political statement, the information must be easy to remember, free from various biases, in order to capture the attention of the political audience. Secondly, as mentioned above, a political statement is focused on influence, so the ability to persuade and motivate is also a characteristic. One of the most important requirements is that any political statement should aim to convince a political audience of the accuracy and credibility of the information contained in the author's message. The following classification of the functions of a political statement is the most complete:

1) to attract attention;

2) an ideological function (a vision of the situation: what problems should be solved and how to solve them);

3) to convince the audience of the correctness of the objectives set and the proposed ways of solving them;

4) mobilise the audience to support the author's proposals [1.23].

Any political statement can encourage you to change the political situation for the better or vice versa. The functions of a political statement are very clearly reflected in advertisements and slogans, leaflets, political speeches and articles, and political publications. Political statement by their function can be represented by the following genres:

- Ceremonial genres (inaugural speech, welcoming speech, etc.);

- Orientation genres (decrees, reports, treaties);

- Agonal genres of political statement (slogan, leaflet, rally speech). Such texts contain calls to struggle and are characterized by increased expressiveness;

- Information genres (newspaper information, statements of politicians in the media). Oral speech genres when comparing oral and written speech (speeches at negotiations, rallies and meetings, lectures, conversations, interviews, etc.) [8. 78].

Oral speech has a greater potential to influence the audience than written communication. In countries 
CURRENT RESEARCH JOURNAL OF PHILOLOGICAL SCIENCES 2(12):

227-231, December 2021

DOI: https://doi.org/10.37547/philological-crjps-02-12-43

ISSN 2767-3758

(C2021 Master Journals

Crossref do

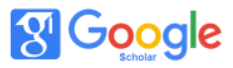

Accepted26 $6^{\text {th }}$ December, 2021 \& Published $31^{\text {th }}$ December, 2021

with an oral political culture, the emphasis is on public speaking rather than official writing. For a politician, direct, live communication with the audience, for example, during meetings with voters or press conferences, is important. There are clear differences between the types of political communication: The structure of oral and written political texts depends directly on how the message is conveyed to the addressee.

Oral speech has its own set of rules of construction, for example, the speech consists of an introduction, the main part and a conclusion, but the number of topics covered by oral communication is often limited. Oral presentation is characterized by certain techniques used to enhance the impact on the recipient. These include both lexical and grammatical techniques. The differences between oral and written texts can be explained by the following reasons: firstly, the different nature of the relationship between the speaker, the audience, the author and the addressee-reader, and secondly, the specifics of understanding the text.

Speech can be dialogic and monological, so political texts distinguish between genres of monologues, including, for example, newspaper articles, radio broadcasts, dialogic genres (parliamentary debates, debates, negotiations, etc.) [3. 55]. Another aspect characteristic of political texts is that in such texts the issue of authorship does not belong to anyone or to the same person. The author of a political text is the politician who uttered the text or the person responsible for the text [3.56].

Although the speeches of political leaders are created by experts in the field, the responsibility lies with them, because the text was published by a politician, and this also has its difficulties. Another aspect of the question of authorship of a political text is that certain types of texts include, for example, the constitution of a country that has no specific author, so we can say that government agencies are responsible for its content.

For this type of text, we consider incoming slogans to be an anonymous political text, although we have inferences about the existence of an author of such texts. On October 24, 2021, the "Election of the President of the Republic of Uzbekistan" took place. However, on the eve of the election, the Qalampir.uz article "Shavkat Mirziyoyev will visit Russia in November" [9] was met with negative publicity. According to the report, Uzbek President Shavkat Mirziyoyev will visit the Russian Federation in November this year. This was reported by the press service of the president of Uzbekistan. [9].

According to the website Qalampir.uz, "On October 24 this year, Uzbekistan will hold presidential elections. It is unknown at this point what he will do after he leaves office. [9]. This message and the site's reaction to it caused public distrust in the elections, the politics of our country, and various protests. According to the Electoral Code of the Republic of Uzbekistan (approved by the Law of the Republic of Uzbekistan of 25.06.2019 № ZRU-544) "Article 65. Assumption of office by the President of the Republic of Uzbekistan.

The President of the Republic of Uzbekistan shall take office within two months from the date of the official announcement of the results of the presidential election by the Central Election Commission at a joint session of the Oliy Majlis of the Republic. Uzbekistan.

The incumbent President of the Republic of Uzbekistan shall exercise his powers until the inauguration of the newly elected President of the Republic of Uzbekistan." [9]. If we count two months from October 24, 2021, this includes the period until December 23, 2021. The last paragraph of this article of the Electoral Code provides that the 
CURRENT RESEARCH JOURNAL OF PHILOLOGICAL SCIENCES 2(12):

227-231, December 2021

DOI: https://doi.org/10.37547/philological-crjps-02-12-43

ISSN 2767-3758

(C2021 Master Journals

Crossref do

81 Google

Accepted26 ${ }^{\text {th }}$ December, 2021 \& Published 31 th December, 2021

current president exercises his powers until the election of a new president. It turns out that the political message published by the press secretary of the President is not illegal and is not controversial.

It is very important to consider the level of people in presenting such political messages, and social media journalists should be politically vigilant in such situations. In order to avoid such misunderstandings, which often occur in active political processes in our country in understanding political texts published in social networks, it has become customary to make comments, often logically justified or not.

One of the most important features of the formal style is that the formal style is equally understood by everyone. However, there have been cases in which official speeches have not paid due attention to this. Today there is a Resolution of the Cabinet of Ministers on the Examination of Political Texts "On Approval of the Regulation on the Procedure of Linguistic Examination of Draft Resolutions" (Resolution No. 662 of October 28, 2021) [11].

Chapter 3 of this decree. According to the requirements of the linguistic examination of the draft is defined as follows.

9. The text of the draft is subject to linguistic expertise based on the following requirements:

simplicity and conciseness of sentences, accuracy of definitions;

Compliance with spelling, methodological, grammatical and orthographic rules;

new terms, as well as the correct use of industry terms;

correct interrelation of phrases;

structure and expressive sequence of presentation.

[11]

Chapter 3 According to the requirements of the linguistic examination of the project, it is advisable to conduct a linguistic examination of social media texts.

It is clear that the legal document expressed the need for what tasks should be performed. However, it does not provide a scientific basis for the implementation of such tasks, which makes a serious study of the forms, methods and features of linguistic examination of political texts an urgent task.

\section{REFERENCES}

1. Бондаренко С.В. 2005. Политическая идентичность в киберпространстве. Политическая наука. № 3. С. 76-92. Бондаренко Н.A. 2010.

2. Интенциональность социального поведения как философская проблема: дис. ... к.филос.н. М. 160 с. Василенко И.А. Политическая философия: учебное пособие. М.: Инфра-М. 320 с. Мирошниченко И.В. 2013.

3. Социальные сети в российской публичной политике: дис. ... д.полит.н. М. Михайленок О.М., Щенина О.Г. 2018. Антропологическое измерение политики: новый «сетевой человек». - Вестник Московского государственного областного университета (электронный журнал). № 2. С. 1-14. Михайлов И.Ф. 2015.

4. Неъматов Х., Менглиев Б., Хамроева Ш. Тилшуносликнинг методологик масалалари. - Германия: Globe,2020

5. Идентичность как категория политической науки: словарь терминов и понятий. 2012. М.: РОССПЭН. 208 с. общества. СПб: Изд-во СПбГУ. 258 с. Пятигорский А.М. 2010.

6. Неъматов Х., Менглиев Б., Ботирова А. Тилшуносликнинг амалий масалалари. (Монография) - Германия: Globe, 2020.

7. Неъматов Х., Менглиев Б., Ботирова А. Тилшуносликнинг фалсафий масалалари. 
CURRENT RESEARCH JOURNAL OF PHILOLOGICAL SCIENCES 2(12):

227-231, December 2021

DOI: https://doi.org/10.37547/philological-crjps-02-12-43

ISSN 2767-3758

(C)2021 Master Journals

Crossref doi 81 Google

Accepted26 ${ }^{\text {th }}$ December, 2021 \& Published 31 ${ }^{\text {th }}$ December, 2021

(Монография) - Германия: Globe, 2020.

8. Зеленко И.Б.Политическом смысле в социальных сетях (интенциональный контекст) Власть 2018'08

9. Интенрен манба:

https://qalampir.uz/uz/news/noyabr-oyidashavkat-mirziyeev-rossiyaga-boradi-47306

10. Ўзбекистон Республикасининг Сайлов кодекси (ЎзР 25.06.2019 й. ЎРҚ-544-сон Қонуни билан тасдиқланган)

11. https://lex.uz/docs/ 5701504 